\title{
The influence of hydro-climatic and anthropogenic effects on the long-term variation of commercial fisheries in a large floodplain river
}

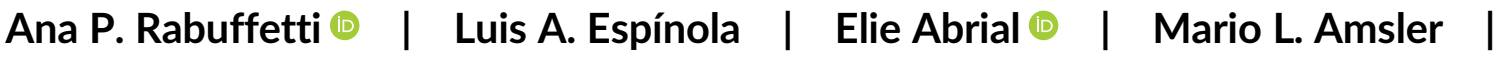 \\ Maria F. Eurich | Martín C. M. Blettler
}

National Institute of Limnology (INALI, CONICET-UNL), Santa Fe, Argentina

\section{Correspondence}

Ana P. Rabuffetti, National Institute of Limnology (INALI, CONICET-UNL), Santa Fe, Argentina.

Email: piarabuffetti@gmail.com

Funding information

Consejo Nacional de Investigaciones Científicas y Técnicas, Grant/Award Number: PIP: 438; National Agency for the Promotion of Science and Technology, Grant/Award Number: PICT: 1855

\begin{abstract}
This study deals with the effects of climate fluctuations and anthropogenic impacts on fisheries of Paraná River over the last 100 years. It is the first attempt to appraise the influence of hydro-climatic and anthropogenic variables on the population changes of the most important inland fisheries of Argentina. Datasets covering more than eight decades (1935-2016) of a number of frequent and abundant commercial species inhabiting the main channel as well as the large floodplain of Paraná River were used. Our results suggest that fish catches and structure changed over time. Long and short-term changes and reductions were closely related to fluctuations of 18 hydroclimatic variables. Positive effects on the ichthyofauna were recorded during humid periods (1930-1940 and 1970-2000), when the frequency of large spring-summer floods increased. An increase in anthropic impacts (accounted for with nine variables) were recorded during the last two decades. We highlight the usefulness of the approach to support the management of the resources, ensuring sustainability of commercial fish assemblages and the long-term conservation of biodiversity in big rivers.
\end{abstract}

\section{KEYWORDS}

anthropic impacts, changes of fishery populations, discrimination of effects, long-term hydrologic fluctuations, Paraná River (Argentina)

\section{INTRODUCTION}

Large floodplain rivers are some of the most heterogeneous and productive ecosystems in the world, sustaining significant biodiversity. The changes in the assemblage of fish species inhabiting such rich ecosystems depend closely on the degree of connectivity between floodplain environments, since it regulates the availability of habitats used for feeding, nursery, spawning, growth and shelter (Abrial, Espínola, Rabuffetti, Amsler, \& Wantzen, 2018; Espínola et al., 2016; Górski et al., 2013; Junk, Bayley, \& Sparks, 1989; Scarabotti, Demonte, \& Pouilly, 2017; Winemiller, 2004). Periodically, long-lasting and intense flood pulses inundate vast floodplain areas that play a key role in fish community dynamics. Productivity, reproduction, recruitment and the diversity of fish populations are positively affected when floodplain connectivity increases due to hydrological inundation events (Górski et al., 2013; Rossi, Cordiviola, \& Parma, 2007; Winemiller, 2004).

Large floodplain rivers have been crucial sites for the development of civilizations since ancient times and remain vitally important for modern society. During the 20th century, large rivers experienced major changes as a result of multiple anthropogenic uses (Best, 2018; Schramm Jr., 2017). Many large rivers support agricultural and industrial activities, and hydroelectric development, and have a central role in retaining water, mitigating floods, breaking down pollutants and providing sources of food and water (Schramm Jr., 2017). In particular, fisheries provide a major nutritional resources and constitute a significant source of livelihood for many people (FAO, 2016). Production for 
human consumption increased since the 1970s around the world. In 2014, global total catches of fish from inland waters were approximately 12 million tons. It is estimated that 56.6 million of people are engaged in the primary fisheries and aquaculture sector (FAO, 2018). Fisheries in La Plata basin in Argentina generates important income through export (approximately $\$ 113$ million between 2007 and 2013; FAO, 2016).

The Paraná River, the main artery of the La Plata basin, has been affected by various types of human activities since the second half of the 20th century (e.g., construction of dams, overfishing and contamination) with possible negative impacts on fish habitats and fisheries (Baigún, Minotti, \& Oldani, 2013; Etchegoyen, Ronco, Almada, Abelando, \& Marino, 2017). Many of these anthropic disturbances could have affected the natural hydro-climatic cycle, resulting in this river being in the top 10 at risk on the planet (Wong, Williams, Pittock, Ollier, \& Schelle, 2007).

In its middle reach (locally called the Middle Paraná River, MPR), the main channel with its floodplain comprises a complex and dynamic ecosystem with heterogeneous lotic/lentic environments. The river is inhabited by numerous fish species ( 240 native species; Rossi et al., 2007), but dominated by around 20 species of commercial value (Espinach Ros et al., 2012). The bulk of freshwater fisheries in Argentina is concentrated in this reach (Espinach Ros et al., 2012; Fuentes \& Quirós, 1988). When considering the reproduction and recruitment of fisheries in MPR, previous studies have shown that frequent springsummer floods of greater than $6 \mathrm{~m}$ water height (measured at the gauging station at Santa Fe city), lasting more than 80 days and with extended rising waters slope are the optimum hydrologic conditions for sustaining the fisheries (Abrial et al., 2018; Rabuffetti, 2018; Rabuffetti et al., 2016).

While the effects of hydro-climatic variations on fish assemblages are fairly well documented for large floodplain rivers (e.g., Espínola et al., 2016; Górski et al., 2013; Junk et al., 1989; King, Humphries, \& Lake, 2003; Winemiller, 2004), there is little research on commercial fisheries (with a focus on the anthropogenic impacts). In addition, thus far little consideration have been given to socioeconomic variability of the fisheries (e.g., changes in fishing activity Quirós, 1990; Del Barco, 2000; Baigún et al., 2008). Moreover, research identifying and quantifying the relative effects of hydro-climatic and anthropic factors on fisheries, which is crucial for the design of fisheries management measures, but largely absent in the literature. In this study, this issue is tackled by analyzing the long-term variability of commercial fisheries in the MPR (1935-2016), focusing on the effects of the hydroclimatic versus the anthropic components. The anthropic component was mainly considered using variables related to fishing.

\section{2 | METHODS}

\section{1 | Study area}

Paraná River is a large river, ranked ninth among the largest rivers in the world based on its mean annual discharge to the ocean $\left(18,000 \mathrm{~m}^{3} \mathrm{~s}^{-1}\right.$; Latrubesse, 2008). We studied lotic/lentic sites located along the floodplain of the MPR ( 700 km, Figure 1). The extensive and complex adjacent floodplain covered by numerous secondary channels, lakes, islands and wetlands is largely unaltered (Latrubesse, 2008). Unlike the characteristics of Upper Paraná in Brazil where numerous large dams have been built since the late $60 \mathrm{~s}$ (Agostinho, Pelicice, \& Gomes, 2008), the MPR remains largely unregulated.

The study area was subdivided in two sections (northern and southern; Figure 1) according to structural characteristics of the fisheries (Espinach Ros et al., 2012). The northern section extends from the confluence of the Paraná River with its main tributary, the Paraguay River, to San Javier city. The southern section begins downstream to San Javier city and ends at Diamante city.

\subsection{Commercial fisheries data}

Fishery catch data were obtained from four sources:

1. National Directorate for Inland Fisheries of Argentina: generated the historical set of official statistics (commercial catches: points 1-2, 7-8, 10; Figure 1) for Argentine Inland Fishery Production (PPARG, for its Spanish initials, 1935-1983).

2. Ministry of Production, General Sub-directorate of Ecology of Santa Fe Province: provided a dataset of fiscal fishing records (commercial catches: points 3-6, 9; Figure 1) for Santa Fe Province (PPSF, for its Spanish initials, 2011-2015).

3. National Institute for Limnology of Argentina (INALI, for its Spanish initials): generated data of fish [total weight ( $\mathrm{Wt} ; \mathrm{g})$ ] caught in lotic/lentic environments of the floodplain (1964-1996, Figure 1).

4. Laboratory of Hydroecology (part of INALI): provided records of fish fauna (Wt; $g$ ) from lotic/lentic environments in a particular sections of the floodplain (LH, 2009-2016, Figure 1).

These datasets formed a long-term series covering more than 50 years of information on commercial fish species. The largest gaps were concentrated in the 1950s and between the period 1997 and 2008. Details and descriptions of different datasets, the analyses carried out to select sites/ports and species in the same area, and the sampling method and effort applied per dataset were described in detail in the methodology reported by Rabuffetti et al. (2016) and Rabuffetti (2018). The most frequent and abundant species common to the different datasets that appear along the analyzed period were selected (Table 1). Since each database applies different effort and sampling methods, each database was analyzed separately.

\section{3 | Hydro-climatic and anthropic datasets and analyses}

Daily water levels for the Paraná River for the Santa Fe Port's gauge (Figure 1) during the studied period were provided by the National 
FIGURE 1 Studied area (MPR in Argentina). Numbers: ports where commercial fisheries data were obtained. fd: flow direction. Source: Modified from Rabuffetti et al. (2016)

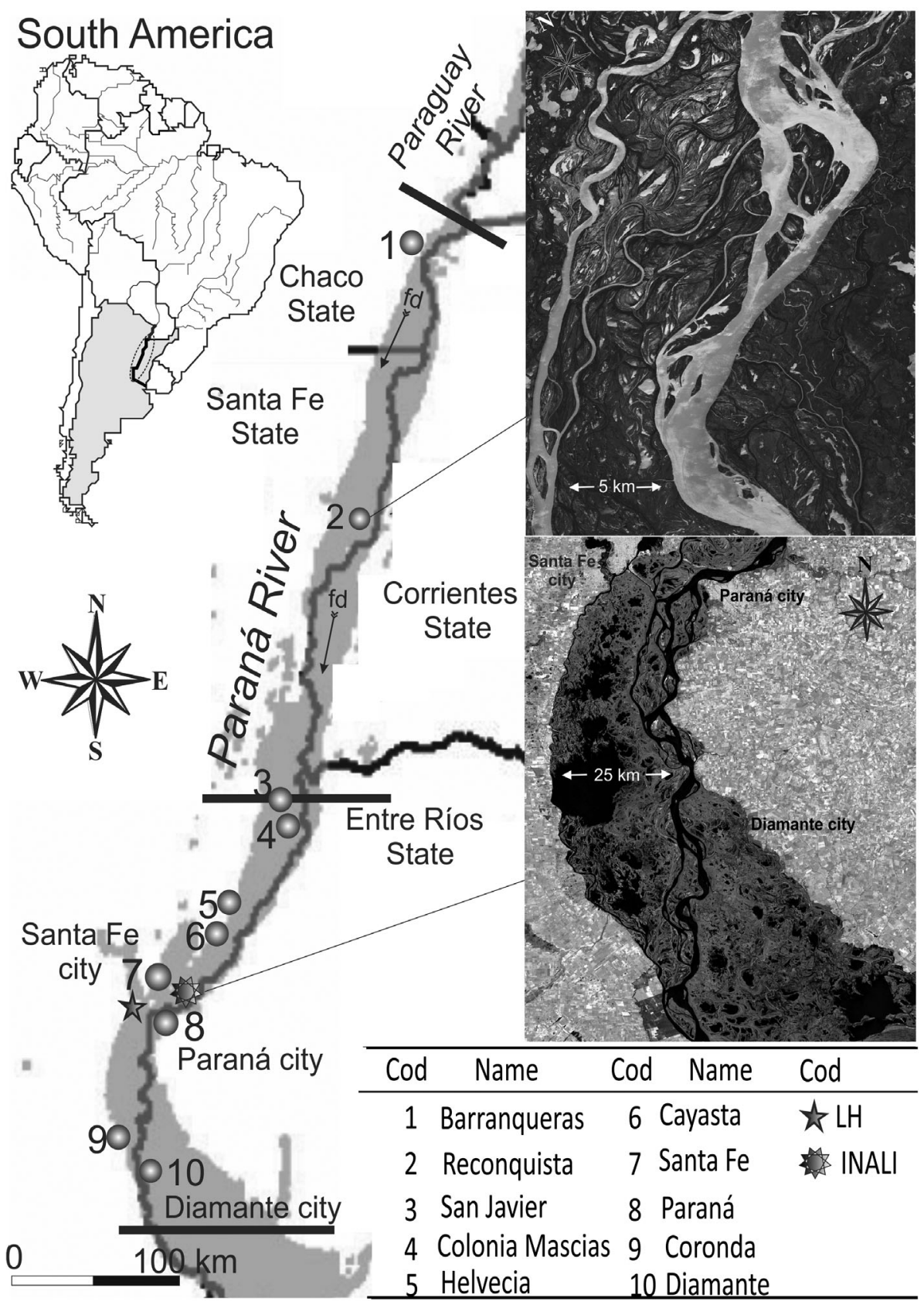

Directorate of Waterways of Argentina. Daily air temperature values were obtained from the National Weather Service of Argentina for Santa Fe city (Figure 1). Since daily records of water temperature were not available, these were estimated according to daily air temperature (see methodology in Rabuffetti et al., 2016). The analyses of temporal variations of the flow regime (1935-2016) involved examination of 18 hydrological variables obtained from daily data records of water and temperature, which were described in the methodology of Rabuffetti et al. (2016).

The anthropic fisheries database contains qualitative and quantitative variables related to inland fishing activity that was obtained from a variety of different sources. The following organizations were consulted: at the national level: Ministry of Treasury and Public Finance, Undersecretary of Agriculture, Livestock and Fisheries, and Ministry of
Agriculture and Industry; at the provincial level: official publications of the Ministry of Production; and at the local level: historical archives of newspapers and universities from Santa Fe city. In each institution, an exhaustive bibliographic search was carried out to gather available information from official reports and statistics, scientific publications, newspaper records and census information, from which annual records were obtained to define the variables (1935-2016; Table 2).

Both hydro-climatic and anthropic datasets were analyzed together in order to discriminate and define key variables associated with variations in fish catches for the main commercial species from the MPR over time.

Interannual variations in the number of fishermen and inhabitants were evaluated through correlations (polynomial tendency) to characterize temporal changes of some anthropic variables. Subsequently, 


\begin{tabular}{|c|c|c|c|c|c|c|c|}
\hline Species & Code & $\mathrm{CN}$ & RS & PPARG & INALI & PPSF & LH \\
\hline Hoplias aff. malabaricus & $\mathrm{H}$ mal & Tararira & PC & - & $x$ & $x$ & $x$ \\
\hline Luciopimelodus pati & L pat & Patí & LM & $x$ & $x$ & $x$ & - \\
\hline Megaleporinus obtusidens & Mobt & Boga & LM & $\mathrm{x}$ & $x$ & $x$ & $x$ \\
\hline Piaractus mesopotamicus & P mes & Pacú & LM & $x$ & $x$ & - & - \\
\hline Pimelodus sp. & Pim sp & Bagre & LM & $x$ & $x$ & $x$ & $x$ \\
\hline Pimelodus albicans & $P$ alb & Bagre & LM & $x$ & $x$ & - & $x$ \\
\hline Prochilodus lineatus & $P$ lin & Sábalo & LM & $x$ & $x$ & $x$ & $x$ \\
\hline Pseudoplatystoma sp. & Pse sp & Surubí & LM & $x$ & - & $x$ & - \\
\hline Pterodoras granulosus & P gra & Armado & LM & - & $x$ & $x$ & - \\
\hline Salminus brasiliensis & S bra & Dorado & LM & $x$ & $x$ & - & $x$ \\
\hline
\end{tabular}

TABLE 1 Commercial fish species recorded per dataset

Note: Code: codes used in graphs; CN: local common name; RS: reproductive strategy (PC: sedentary fish with parental care and external fertilization; LM: long-distance migratory fish with external fertilization and without parental care); PPARG: Argentine Inland Fishery Production (1935-1983); INALI: National Institute for Limnology of Argentina (1964-1996); PPSF: fiscal fishing records for Santa Fe Province (2011-2015); LH: Laboratory of Hydroecology (2009-2016).

TAB LE 2 Anthropic variables selected to characterize fishing activity in MPR

\begin{tabular}{|c|c|c|}
\hline Variables & Code & Description of variable \\
\hline $\begin{array}{l}\text { Fishing } \\
\text { prohibition }\end{array}$ & Vedas & $\begin{array}{l}\text { SV: Without restrictions } \\
\text { VCV: Restrictions on beef } \\
\text { VCP: Restrictions on fish meat } \\
\text { VTS: Temporal restriction of } \\
\quad \text { Prochilodus lineatus. }\end{array}$ \\
\hline $\begin{array}{l}\text { Number of } \\
\text { fishermen }\end{array}$ & $\begin{array}{l}\text { No of } \\
\text { fishermen }\end{array}$ & $\begin{array}{l}\text { Number of fishermen in Santa } \\
\text { Fe state with official annual } \\
\text { record. To complete the } \\
\text { missing information the series } \\
\text { was filled by estimation of } \\
\text { missing data. }\end{array}$ \\
\hline $\begin{array}{l}\text { Capture } \\
\text { method }\end{array}$ & Capture & TT: Trammel net. RE: Gillnets. \\
\hline $\begin{array}{l}\text { Consumption } \\
\text { per capita }\end{array}$ & $\begin{array}{l}\text { Consum per } \\
\text { capita }\end{array}$ & Per capita fish consumption. \\
\hline Exportation & Exportation & $\begin{array}{l}\text { Catches in tons of Prochilodus } \\
\text { lineatus. }\end{array}$ \\
\hline Demographic & $\begin{array}{l}\text { No of } \\
\text { inhabitants }\end{array}$ & $\begin{array}{l}\text { Number of inhabitants; official } \\
\text { census of Argentina. }\end{array}$ \\
\hline $\begin{array}{l}\text { Destination } \\
\text { resource uses }\end{array}$ & Destination & $\begin{array}{l}\text { Artisanal (fishmongers) } \\
\text { Industrial activity (commercial } \\
\text { fishing) }\end{array}$ \\
\hline $\begin{array}{l}\text { Level of } \\
\text { exploitation }\end{array}$ & Exploitation & $\begin{array}{l}\text { Underexploited (moderate } \\
\text { activity) } \\
\text { Overexploited (intensive } \\
\text { activity) }\end{array}$ \\
\hline $\begin{array}{l}\text { Production } \\
\text { system }\end{array}$ & Production & $\begin{array}{l}\text { Subsistence: Artisanal activity. } \\
\text { Industrial: Capitalist system, the } \\
\text { fisherman is an informal } \\
\text { employee. }\end{array}$ \\
\hline
\end{tabular}

Note: Significant and non-collinear selected variables are highlighted in bold.

the associations between hydro-climatic and anthropic variables were summarized using principal component analysis (PCA) to reduce the dimensionality of the data. According to the Kaiser-Guttman criterion, only axes with eigenvalue $>1$ were retained for interpretation (Jackson, 1993). Pearson correlations were used to identify the variables that contributed most $(r>0.60)$ to the retained axes.

\subsection{Spatial and temporal changes in commercial fisheries}

Annual fish abundance (catches in tons) of the seven most abundant and frequently recorded species was analyzed to evaluate fluctuations in commercial fish assemblage structure throughout the study period. Interannual variations of the datasets from PPARG (1935-1983) and PPSF (2011-2015) along the river corridor were compared by applying a graph of overlapping columns considering subdivisions of sections along the MPR (Figure 1).

\section{5 | Significance of variables. Commercial fish catches}

Redundancy analysis (RDA) based on the most frequent and abundant species within each dataset (Table 1) was used to analyze the effects of hydro-climatic and/or anthropic variables on the variability of commercial catches (PPARG and PPSF) and identify key variables influencing assemblage structure. Adjusted $R$-squared values and correlation coefficients among variables were assessed, and a forward selection analysis was applied.

Subsequently, a multivariate ecological analysis, a procedure of variance partitioning (Peres-Neto, Legendre, Dray, \& Borcard, 2006), was applied to determine the degree of significance of each set of explanatory variables over time, and to quantify the percentage of variation explained by each set of variables. In both methods, explicative variables were selected by considering correlations $(r>0.60)$, significance $(p<.05)$ and variance inflation factor (VIF $<5)$. 


\subsection{Fish catches and principal variables}

Interannual fluctuation in official records of commercial catches of Prochilodus lineatus from Paraná River between 1925 and 2016 were analyzed, since it is the most representative species in the system (Rossi et al., 2007). It is a key species in Santa Fe and Entre Ríos (Del Barco, 2000) for two reasons: (1) the bulk of the anthropic procedures are focused on this species; and (2) it has a fundamental ecological role, since it is at a base level in the food chain.

The analysis was first focused on the interannual variability of the characid $P$. lineatus to elucidate which variables were most significant and best accounted for the changes observed in fisheries. $P$. lineatus is the most frequent and abundant species on the floodplain and it was present throughout the study period with numerous records in all data series examined (1935-2016). Considering the type and quality of data contained in our dataset (LH: Laboratory of Hydroecology), catches were divided into two-size ranges according to different life stages of the species (young individuals $<25 \mathrm{~cm}$ of standard length SL-, preadults/adults $>25 \mathrm{~cm} \mathrm{SL}$ ). The distinction arises to consider the range of sizes at first maturity of the species (length at which $50 \%$ of the fish have reached sexual maturity, between 25 and $30 \mathrm{~cm} \mathrm{SL}$; Rossi et al., 2007).

A PCA was applied to the PPSF dataset to evaluate temporal structuring and relationships between hydro-climatic and anthropic variables and catch data for $P$. lineatus. When it was necessary to incorporate categorical (qualitative) variables, a Multiple Factor Analysis (MFA, Escofier \& Pagès, 1994) was used in order to handle heterogeneous sets of variables. To apply MFA analysis, variables were subdivided into two subsets (categorical and quantitative), which were centered, standardized and weighted to assign them equal weights in the global analysis. In final analyses, only significant and non-collinear variables (Pearson's $r>0.6$ ) were considered. In both procedures (PCA and MFA), the Kaiser-Guttman criterion for retained axes was applied. Finally, interannual variation of $P$. lineatus catches was plotted for each dataset with the aim of evaluating temporal fluctuations.

All the axes retained for interpretation in the different analyses were significant. In PCA, differences were tested using an Euclidean

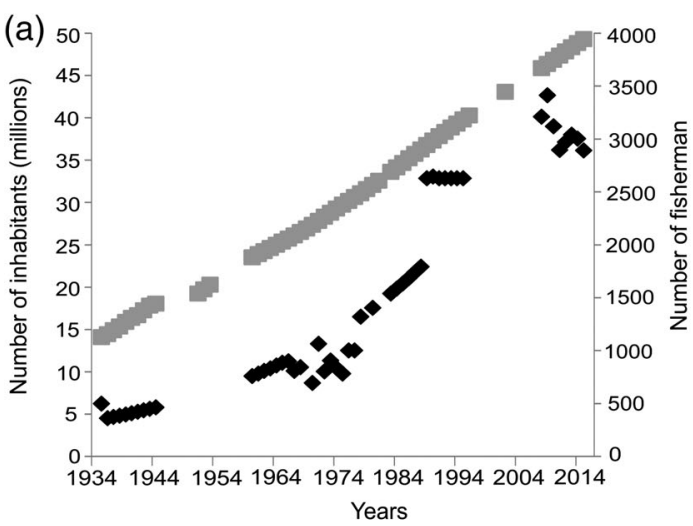

distance matrix, the Bray-Curtis dissimilarity index was used in RDA and MFA; and when it was necessary, probability values were obtained for predictor variables by 999 random permutations without restrictions. All analyses were carried out using $\mathrm{R}$ statistical software (R Development Core Team, 2014). Statistical significance was determined at $p<.05$.

\section{3 | RESULTS}

\subsection{Temporal variation and groups of variables}

Demographic changes in the region resulted in a progressive increase in both the number inhabitants and fishermen throughout the study period (Figure 2a). Since the 1990s the number of fishermen increased above the rate of population growth (Figure $2 b$ ).

PCA identified three different groups of variables (Figure 3). The first group comprised 11 variables (mostly from the 2010s) characterized by anthropic variables, as well as the hydrological variables associated with the timing of floods and number of wet days. The second group gathers principally dry years (17) reflect longer periods of disconnection on the floodplain. The third group comprises 22 years (mostly from the 1980s and 1990s, and also 2010 and 2016) characterized by very long ( $\sim 3$ months) and intense floods ( $\mathrm{Hmax}$ between 4.7-7.4 $\mathrm{m}$ ) frequently coincident with maximum temperatures (spring-summer floods). The most significant and non-collinear variables were selected for subsequent analysis. These and the remaining anthropic variables (five categorical) were used in subsequent analyses.

\subsection{Spatial and temporal variation of commercial fish assemblage}

The structure of commercial fish assemblages changed markedly along the river corridor over time (Figure 4). When comparing the fisheries structure historically (PPARG) and currently (PPSF), a marked change

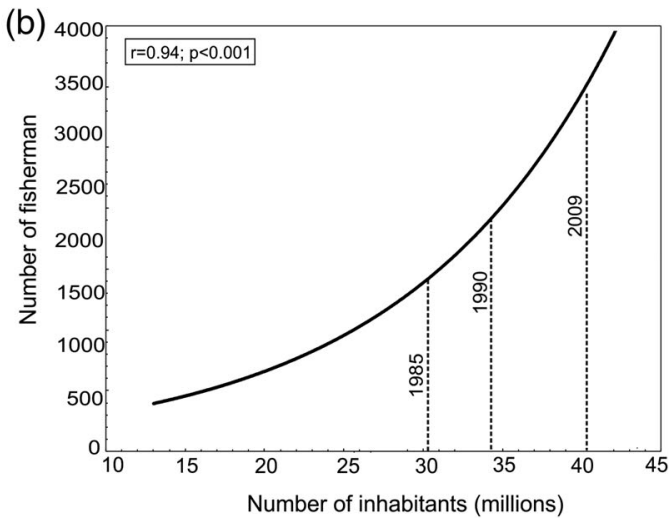

FIGURE 2 (a) Interannual fluctuation (1934-2016) of number of inhabitants (gray dots) and number of fisherman (black dots). (b) Regression function 


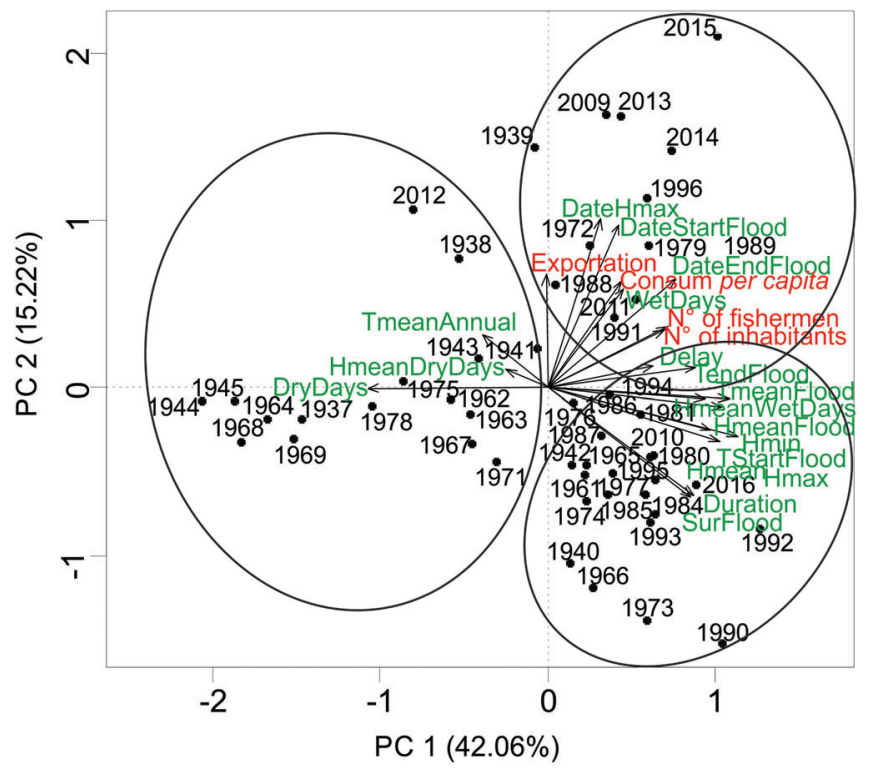

FIGURE 3 PCA showing temporal structure of anthropic (red) and hydro-climatic (green) variables between 1935 and 2016 [Color figure can be viewed at wileyonlinelibrary.com] in composition was observed. This included the disappearance of Piaractus mesopotamicus and Salminus brasiliensis, which were among the most abundant species in the past century. In contrast, Hoplias aff. malabaricus and Pterodoras granulosus have become the dominant species within the current MPR commercial stock. P. lineatus, which has always been present in the commercial stock, showed a progressive increase in catches over time (higher abundance in the southern section). In the current stock, it represents $91.4 \%$ of total commercial biomass of the system at Santa Fe.

During the past century, the abundance of $P$. mesopotamicus, S. brasiliensis (total disappearance between 1973 and 1975) and Pseudoplatystoma sp. were higher in the northern section. Surubí was the most widely caught species throughout the historic period, being dominant in the 70s and 80 s in the northern section but sharply declining more recently. Luciopimelodus pati catches were relatively stable and abundant throughout the whole study period, being a unique species that did not display any marked pattern of temporal variability or spatial preferences. The abundance of Pimelodus sp. was higher in the southern section during the 60s-80s. Catches of Megaleporinus obtusidens indicate a progressive increase over time (more abundant in the southern section). In addition, $M$. obtusidens

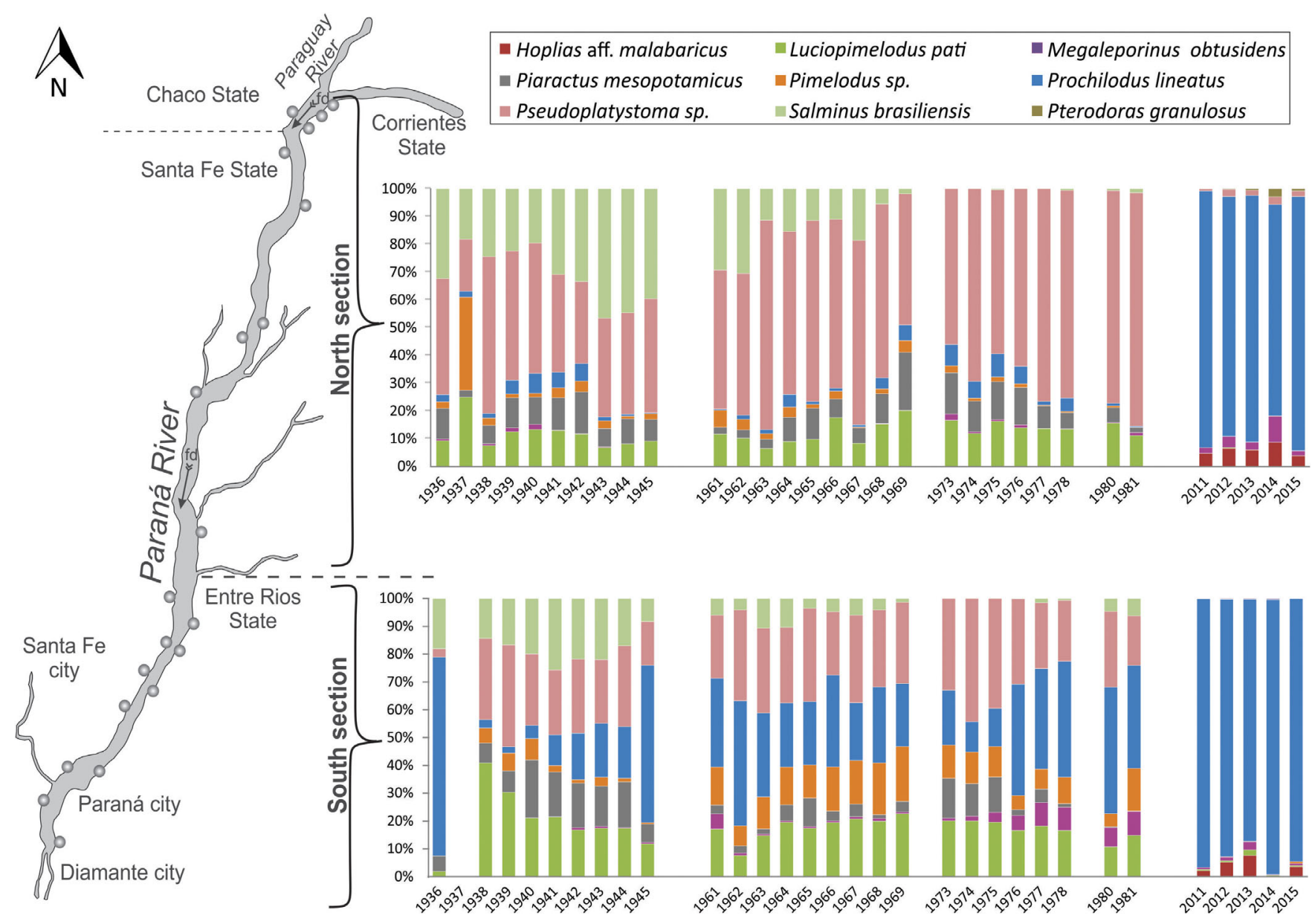

FIGURE 4 Spatial and temporal variations of fisheries structure in sections of MPR (PPARG 1936-1981, PPSF 2011-2015), showing percentage of catches (biomass) of the seven most frequent and abundant species [Color figure can be viewed at wileyonlinelibrary.com] 


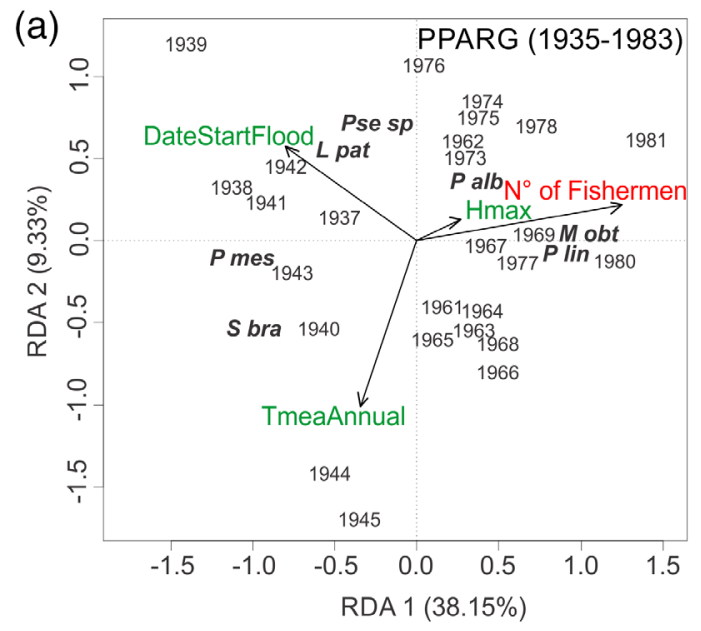

PPARG (1935-1983)

(c)

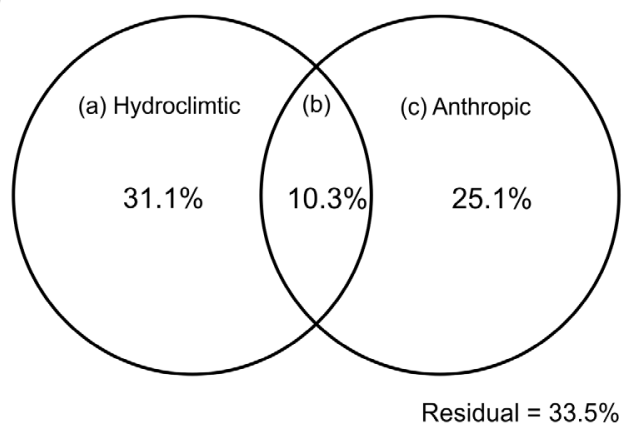

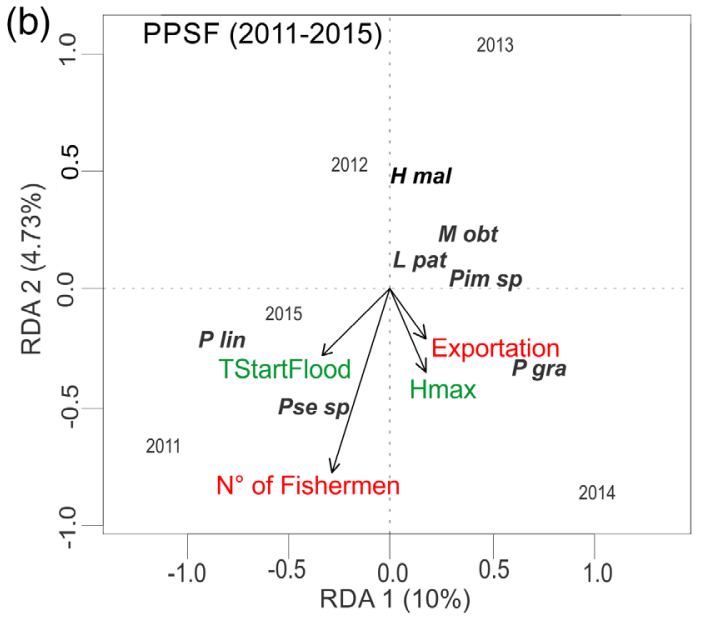

PPSF (2011-2015)

(d)

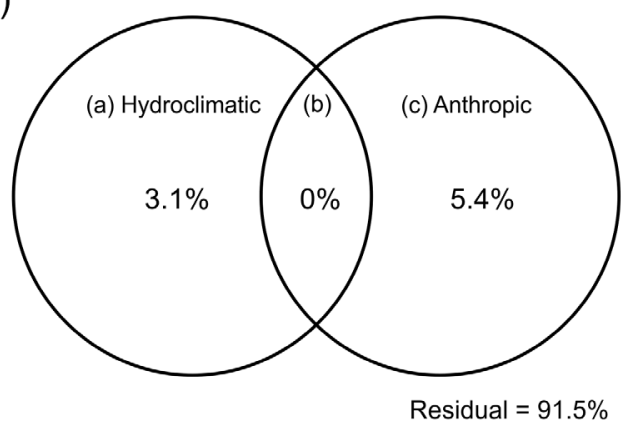

FIGURE 5 (a and b) Redundancy analysis of fish catches in MPR. Variables: hydro-climatic (green), anthropic (red). (c and d) Venn diagrams showing results of the variation partitioning procedure. (a) Hydro-climatic component; (b) Interaction (explained common variation, a + c); (c) Anthropic component; Residual: unexplained variation [Color figure can be viewed at wileyonlinelibrary.com]

represents an important part of the current commercial stock together with catches of $H$. aff. malabaricus.

\subsection{Fish catches: Explicative variables}

The final RA model, that best explained the structure of commercial fish catches over the past century, indicated a dominant effect of hydro-climatic variables (Figure 5a). Axis 1 explained $38.15 \%$ of the total variance of fish catches and was positively correlated with the number of fishermen and maximum intensity of floods (Hmax), and negatively correlated with the date when flooding commenced (DateStartFlood). The temperature was negatively correlated with axis 2. $P$. lineatus, $P$. albicans and $M$. obtusidens were positively correlated with the number of fishermen and Hmax, while, Pseudoplatystoma sp. and L. pati were associated with the timing of the flooding (DateStartFlood). Furthermore, S. brasiliensis was associated with water temperature. Axis 1 for the RDA model for the contemporary period was correlated with anthropic variables and Hmax, while temperature at the beginning of floods (TStartFlood) was negatively correlated with axis 2 (Figure 5b). H. aff. malabaricus, M. obtusidens, L. pati and Pimelodus sp. were strongly correlated with the number of

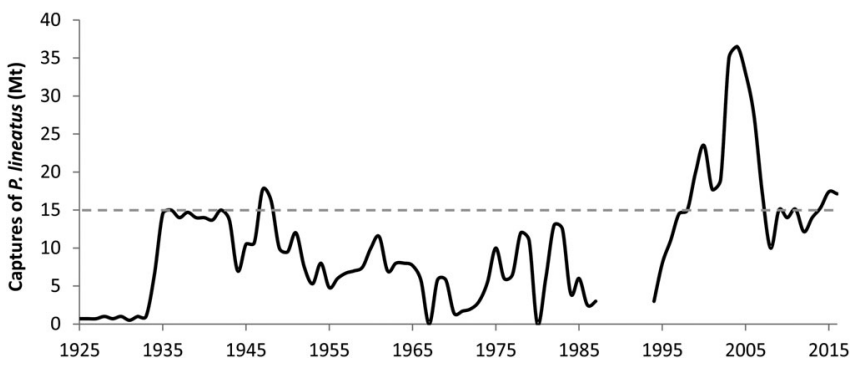

FIG URE 6 Commercial catches (thousand tons, Mt) of Prochilodus lineatus recorded in Paraná basin (Argentina). Period 1925-1987 corresponds to Argentine Continental Fishery Production. Official information is not available for the period 1988-1993. Period 1994-2011 corresponds to exportation records of National Service for Agrifood Health and Quality (SENASA, for its Spanish initials). From 2012 to 2016 information corresponds to National Customs Administration and SENASA of Argentina

fishermen. In contrast, Pseudoplatystoma sp. and P. lineatus were associated with the timing of the start of flooding (TStartFlood).

Variance partition analysis of PPARG indicated different contributions of variable subsets to total variance of commercial 

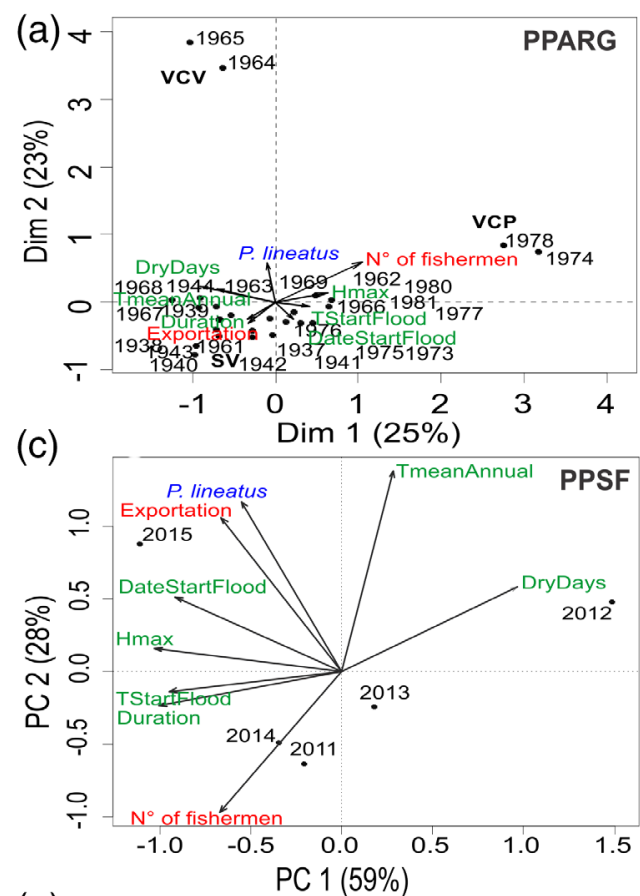

(e)
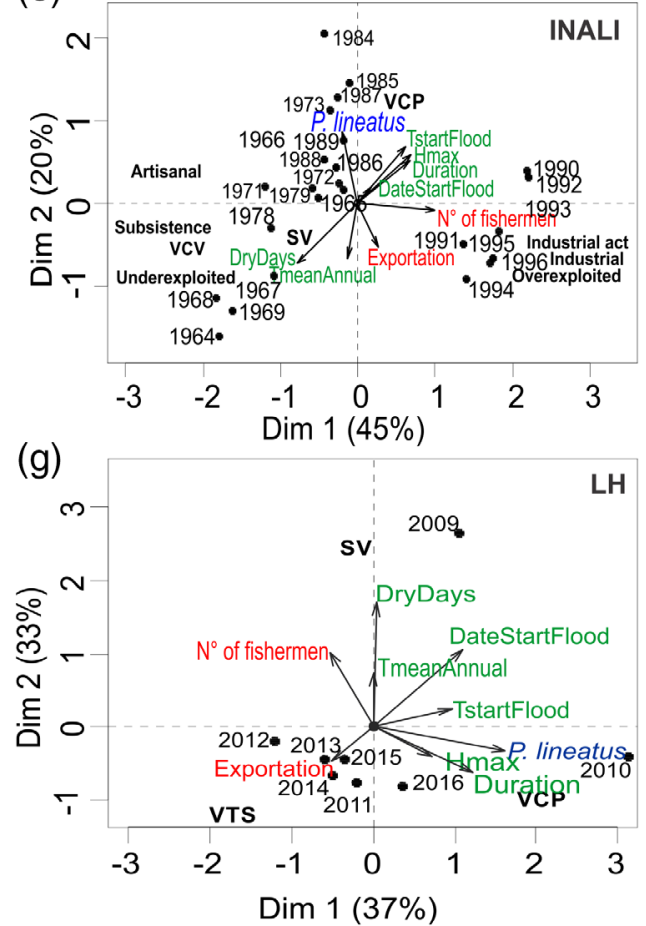

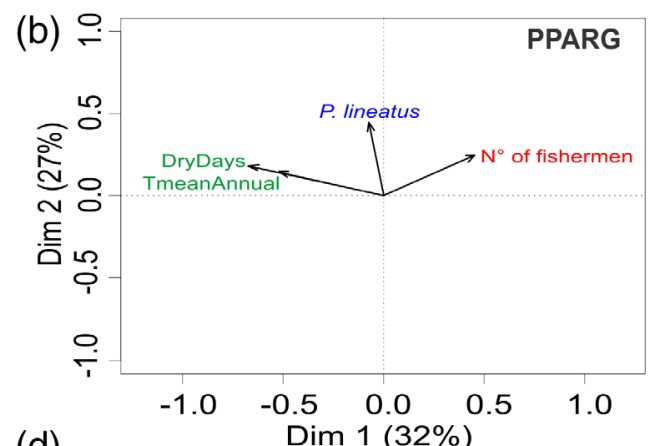

(d)

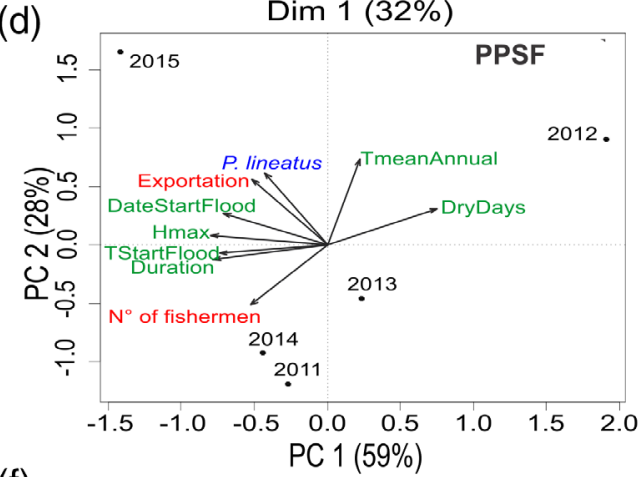

(f)
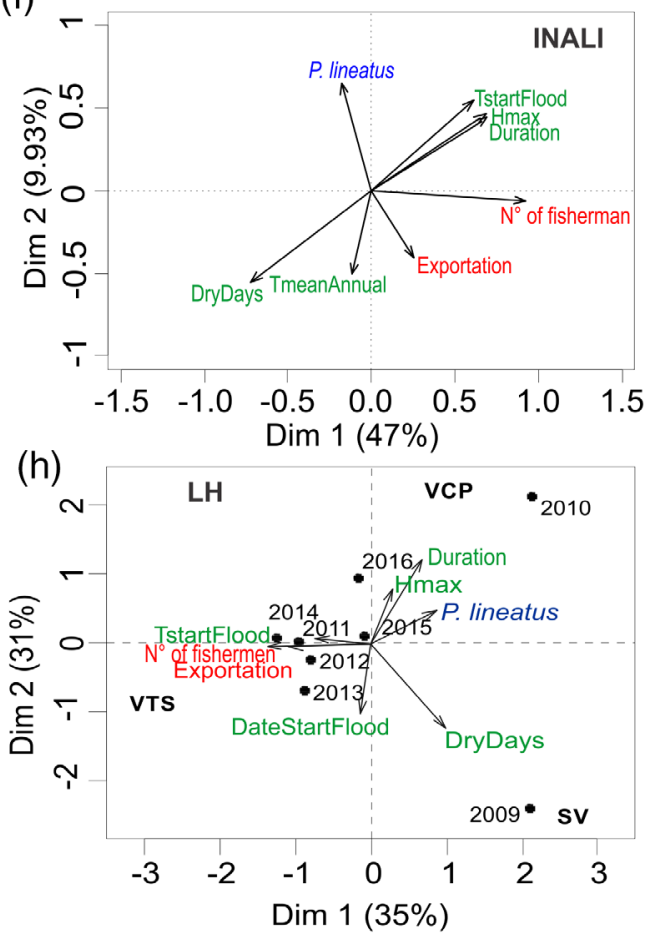

FIGURE 7 Hydro-climatic (green) and anthropic (red) variables related to catches of Prochilodus lineatus. Temporal structuring of catches (a, c, e); final global model (significant and most explicative variables; $b, d, f$ ); (g) individuals with $\mathrm{SL}<25 \mathrm{~cm}$, (h) individuals with $\mathrm{SL}>25 \mathrm{~cm}$ [Color figure can be viewed at wileyonlinelibrary.com] fisheries assemblages (Figure 5c). The highest proportion of variation in commercial catches was significantly accounted for by hydro-climatic factors $(p=.028)$ and to a lower extent by the anthropic parameters $(p<.05)$. The percentage of variance explained by the interaction between components (fraction 10.3\%) was not significant. During the current period, in contract, results for PPSF indicate that the highest percentage of variance in commercial catches was explained by the anthropic component $(p<.05)$ (Figure $5 d$ ).

\subsection{Catches of P. lineatus: Principal variables}

From the beginning of the 20th century to 2016, commercial catches of $P$. lineatus have experiences noticeable changes (Figure 6). Since the 1990s, change in export catches progressively increased, with maximum values recorded between 2003 and 2006. From a baseline of 15 thousand tons that was typically extracted (gray dotted line; note that the average of the analyzed period is still low: $\sim 10 \mathrm{Mt}$ ), 36 thousand tons were caught in 2004. By the end of the 2000s, 
FIGURE 8 Maximum water levels (Hmax, gray line) and interannual fluctuation of Prochilodus lineatus catches per dataset in MPR

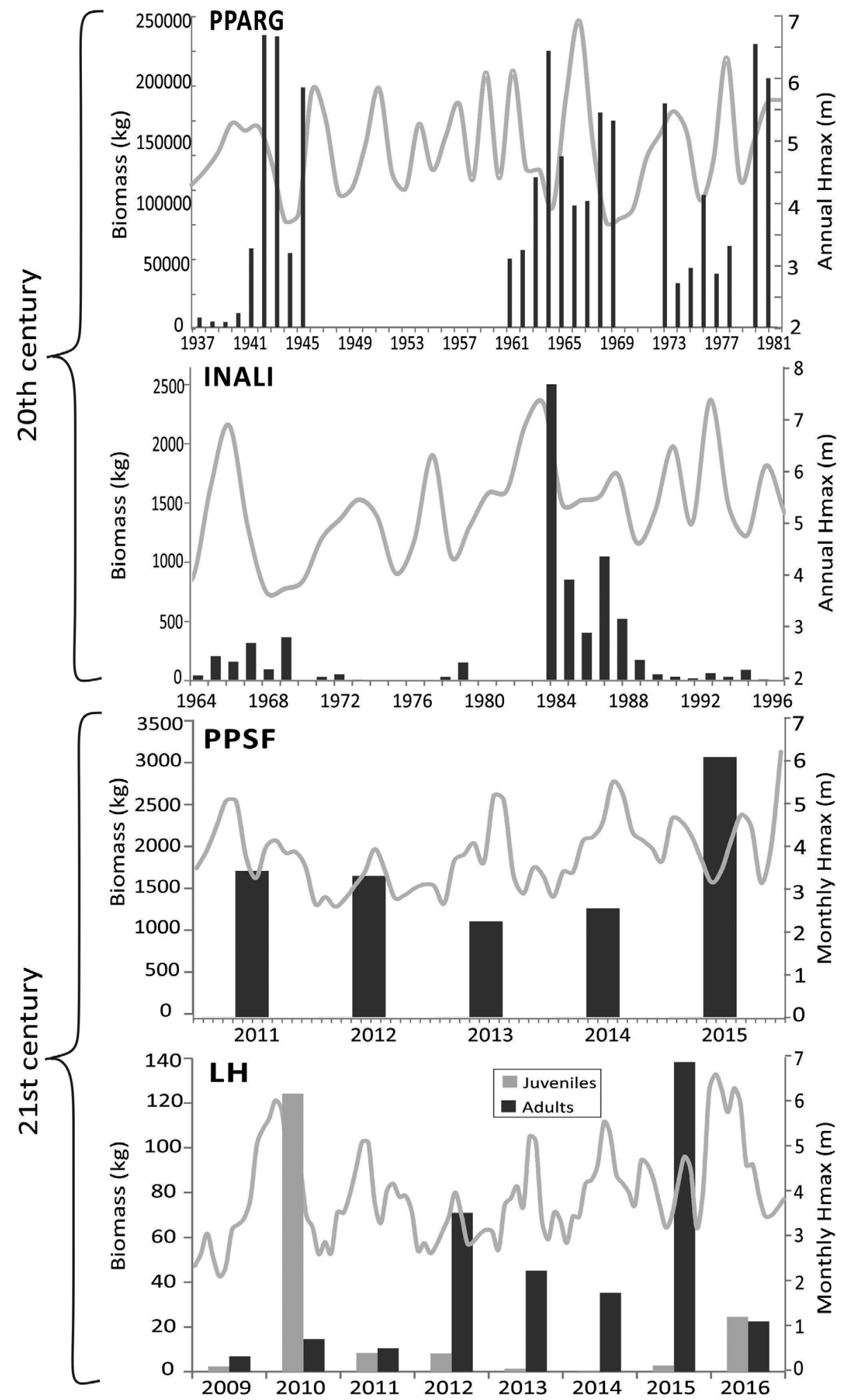

catches were restored to historic levels. Since 2007, catches have been similar to the volumes recorded in the late 1930s and 1940s.

Commercial catches of $P$. lineatus could be structured by a group of hydro-climatic-anthropic variables (Figure 7a-d). High commercial catches were recorded in the early 1940s, and since 1944 they declined markedly (Figure 8). Water temperature at the start of a flood (seasonality) and intensity (Hmax), together with the number of fishermen and catch export, were associated with the highest abundances of fish (e.g., 1941-1942, 1970s, 1980-1981, 2015; Figure $7 a, c)$. However, a marked increase in catches was recorded from 1964 to 1965 during dry years (Figure 8), which was related to a short-term prohibition on beef [restrictions on beef (VCV); 
Figure 7a]. The most powerful variables were those associated with mean annual temperature, characteristics of drought/humid periods, and variation in the number of fishermen (Figure 7b). PCA indicated that catches fluctuated in response to environmental changes and were primarily related to anthropic variables (Figure 7c,d).

In floodplain systems, catches of $P$. lineatus changed in response to hydro-climatic variables (Figure 7e-h). In the 1980s, catches increased markedly, the largest being recorded in 1984, after large flood events 1982-1983 (Figure 8). In both temporal scales, a strong correlation was observed between the largest catches (e.g., 1966, 1984-1985, 2010, 2015-2016, Figure 7e,f and Figure 8) and flooding variables (e.g., duration, maximum intensity and seasonality). For the dataset provided by INALI, all variables associated with anthropic activities in the1990s were important (Figure 7e,f). Juveniles of $P$. lineatus were abundant after the largest spring-summer floods (primarily 2010 and a lower increase in 2016, Figure 8), which was positively associated with flood duration, Hmax and the timing of floods, and negatively associated with Dry Days (Figure 7g). Moreover, larger sizes of $P$. lineatus have become abundant since 2012, with a clear rise in 2015 (Figure 8) correlated with Hmax and the duration of flooding (Figure 7h).

\section{DISCUSSION}

\section{1 | Hydro-climatic versus anthropic effects on fisheries}

Flow regime and temperature varied significantly over time in the MPR. This resulted in the identification of two distinct hydro-climatic periods (two wet/humid periods 1905-1940 and 1970-2000, and a dry period 1941-1960s), which are associated with the intensities and frequencies of the El Niño-Southern Oscillation phenomenon (Camilloni, Saurral, \& Montroull, 2013) resulting from global environmental change (Antico, Schlotthauer, \& Torres, 2014; IPCC, 2014). This hydro-climatic variability has changed the freshwater fisheries community structure over time. Our results indicate that commercial catches fluctuated markedly over time in direct association with variables that quantify flooding characteristics (hydro-climatic component) with a rise in the influence of anthropic variables during the 20th century (Figure $5 d$ ). Given the high percentage of unexplained variance in the dataset provided by PPSF, it is important to highlight that some results should be treated with care since the require detailed examination. This low percentage observed of explanation in datasubsets must be due by so many other abiotic factors that are involved, being this a common result observed in most ecological studies (Arieira, Penha, Nunes da Cunha, \& Guimaraes Couto, 2012; Baldissera, Rodrigues, \& Hartz, 2012). However, the strong comparability with noncommercial catches ( $P$. lineatus; Figure 7$)$ indicates that anthropic variables do not change the responses observed for the different time scales, since catches were primarily structured by hydrological variables.
Hydrological pulsing, mainly the duration, intensity (Hmax) and seasonality (DateStartFlood, TStartFlood) of floods largely governs the functioning of fisheries (Figures 5 and 7). This reflects the regularity of hydrological cycles, while seasonality and variation in temperature affect fish fauna in different ways (Quirós, 1990). Some species (e.g., S. brasiliensis, P. lineatus, Pseudoplatystoma sp., P. granulosus) show significant seasonal behavior, reducing their catches during dry scenarios (Figures 5 and 8). The catches of $S$. brasiliensis decreased between the mid-50s and 60s, and it was not recorded during the period between 1973 and 1975, when fishing was completely banned due to previous reductions recorded in catches (Figure 4; Fuentes \& Quirós, 1988; Rabuffetti et al., 2016). This species display a strongly synchronism between gonadal maturation and photoperiod and appear to be sensitive to variability of water temperature and level (Figure 5; Fuentes and Quirós, 1988).

Optimum spring-summer floods were significantly more frequent and intense within the Paraná basin during humid periods and during the 2010s (Rabuffetti, 2018). Higher catches were associated with these conditions (Figures 5 and 7). Connectivity generated on the floodplain during periods of flooding has been beneficial for fish species (evidenced in P. lineatus, Figure 8; Abrial et al., 2018), since it is known the size of LM populations depends on the welfare of larvae and juveniles during "critical periods" such as flood inundation (McCasker, Humphries, Meredith, \& Klomp, 2014). Fish species take advantage of floods in phase with warm temperatures for their reproduction within lotic habitats, and use the diverse floodplain habitats as nursery areas for larvae and juveniles (Abrial et al., 2018; Winemiller, 2004) and for feeding and shelter (Oldani, Ecclesia, \& Baigún, 2013). These findings coincide with records from other large floodplain rivers, where reproduction, recruitment, and growth of fish have been more successful associated with longer flood durations, larger flooded surfaces, greater intensities (Górski et al., 2013), higher temperatures and the timing of floods (King et al., 2003).

\subsection{Spatial and temporal changes of fisheries}

Composition of commercial assemblages changed markedly over time in MPR (Figure 4). The loss of species of high commercial value (e.g., P. mesopotamicus, S. brasiliensis) was apparent. These species have been replaced by others of less commercial value (e.g., $H$. aff. malabaricus, $P$. granulosus). It is also worth mentioning the significant decrease/increase in frequency and abundance of other species (e.g., Pseudoplatystoma sp. and P. lineatus, respectively; Fuentes and Quirós, 1988). The reduction of migratory species is considered an indicator of environmental problems associated with to anthropic impacts (Baigún et al., 2008, 2013; Winemiller, 2004), causing an impoverishment of commercial fisheries.

Species like $P$. mesopotamicus and Zungaro jahu were have been completely depleted since the 1980s (Quirós, 1990; Scarabotti et al., 2017). The disappearance of $P$. mesopotamicus, which eat fruit and seeds, is noticeable mainly in the southern section since the 1970s (Figure 4). This may be due to the increase in marginal 
deforestation and pollution caused by agrochemicals and industries as a result of urban and industrial development. Recently, juveniles of both species reappeared in floodplain areas after long periods without records (Scarabotti et al., 2017) as a consequence of beneficial hydroclimatic conditions generated by optimum flooding during the 2010s, highlighting the key role of these events in the reproduction and recruitment of individual fish species.

In addition, the abundance and frequency of large-bodied and highly reproductive fish species decreased, which suggests a decrease in sizes (Baigún et al., 2008; Del Barco, 2000). However, some (e.g., Pseudoplatystoma sp., S. brasiliensis) are still more frequent and larger in the northern section of the middle reach (Vargas, 2014). Oldani et al. (2013) postulated that changes were potentially caused by the numerous dams built on the upper reach. Specifically, Yacyreta dam (Misiones, Argentina) has blocked the migratory route of many LM species, including Pseudoplatystoma sp., isolating $\sim 600 \mathrm{~km}$ of the reproduction area. Dams block fish migration routes, negatively affecting riverine communities (Agostinho et al., 2008), and thus causing a functional simplification of the system (Oliveira, Baumgartner, Gomes, Días, \& Agostinho, 2018).

The interruption in commercial records (1985-1994) and generated gaps (especially in the 50s) are clearly unfavorable for analyzing historical datasets, thus making interpretations more complex. It is essential to have complete national statistics referring to continental fishing, especially in relation to the great rivers of the La Plata basin at least to the degree of detail that once existed. The improvement of database by the public institutions is essential to regulate fishing activity at the basin level. In this sense, database needs to be improved in the Middle Paraná River: criteria for measurements and sampling efforts should be unified and database must be available in an open access with updated data providing reliable, systematic and high-quality information. This will allow researchers and stockholders to assess better quantifications of the fishing activity and the commercial assemblage by analyzing, along regular periods of time, various aspects related to the commercial fisheries.

\section{3 | Temporal variation of $P$. lineatus catches}

Fisheries in the lower Plata basin started in the 1930s (Espinach Ros et al., 2012; Prol, 2008). Between 1934 and 1943, catches increased consistently, being higher in the period between 1941 and 1943 (Figure 8), following the humid years of the early 20th century. Official statistics show an improvement in collection of fishery records data in the 1940s. However, catches decreased markedly in 1944 as a consequence of one of the most extreme disconnection events of the last 130 years. Subsequently, during dry decades, catches were lower or similar to the previous period (between 5 and 10 thousand tons per year; Prol, 2008). From 1964 to 1965, drought years, commercial catches increased (Figure 8) after the great spring-summer flood in 1959. In addition, these values coincided with a substantial increase in fishing activity as a result of an increase in per capita consumption (from $3.31 \mathrm{~kg}$ in 1963 to $4.33-4.22 \mathrm{~kg}$ in $1964-1965$ ), as a result of high prices of beef and restrictions imposed for consumption (VCV; Figure 7a; Fuentes \& Quirós, 1988). However, Sverlij and Espinach Ros (1986) argued that it was not possible to directly associate anthropic factors related to fishing pressure with variations in catches, since no significant changes in effort and number of fishermen were reported from 1930 to the 1980 s.

Artisanal fishery activities have been carried out along the lower Paraná basin since 1980 (Del Barco, 2000; Prol, 2008). Exploitation (Figure 6; Baigún et al., 2013), fisheries exports (Iwaszkiw \& Lacoste, 2011) and the number of fishermen (Figure 2; Del Barco, 2000) increased in the late 1990s, since economic conditions became favorable for freshwater fisheries, and more fish meat processing plants were developed (Baigún et al., 2008). Simultaneously, environmental alterations of the floodplain was recorded along the Paraná basin, which may have also resulted in deterioration of water quality as a result of increased agricultural production (Etchegoyen et al., 2017). This might affect the resilience of fish stocks due to changes in ecosystem characteristics (e.g., habitat fragmentation, interruption of migrations, decrease of nurseries; Colautti, Domanico, \& Balboni, 2016).

During the period 1994-2006, catches fluctuated from 2.785 to 27.505 tons, with a maximum of 37.597 tons in 2004 (Iwaszkiw \& Lacoste, 2011). This intensive activity coincided with dry climatic conditions. A period of intensive exploitation of fisheries was recorded between 2003 and 2006 (overfishing period; Baigún et al., 2008, 2013; Prol, 2008; Oldani et al., 2013; Figure 6). In the same period, a decrease in $P$. lineatus mean size from 48 to $42 \mathrm{~cm}$ was recorded, probably caused by a reduction in net mesh size from 16 to $12 \mathrm{~cm}$ (Baigún et al., 2013). Several authors have proposed that an increase in pressure on $P$. lineatus due to the development of fishing activities and the size reduction of this species in the last decades have led to a reduction in the size structure of other species (Baigún et al., 2008; Oldani et al., 2013).

This study represents a first effort to assess anthropic variables of the continental fishing activity (e.g., overfishing, fishing prohibitions, number of fishermen) as factors that could explain an important part of the temporal variations in the commercial catches. However, data reports about inland fisheries (analyzed anthropic variables) may be insufficient and incomplete (FAO, 2018), highlighting the need of carrying out further studies on this issue. On the other hand, considering that the last case of overfishing was recorded under unfavorable climatic conditions for fisheries assemblage, past/present hydro-climatic conditions must be considered when establishing exploitation measures and productive management plans. Taking into account these considerations, the sustainability of freshwater fisheries could be improved.

\section{5 | CONCLUDING REMARKS}

The approach used throughout this investigation, based on the complementary and careful treatment of several fisheries datasets from the MPR, the most important in Argentina, allowed the relative 
importance of long and short term hydro-climatic variables, and anthropic effects on the most abundant and frequent caught commercial species to be determined. Results provided a quantitative explanation of the variability of this important Argentinian resource spanning almost 80 years. The methods used could be applied to other river basins (provided that appropriate information is available) where the sustainability of inland fisheries in large ecosystems needs to be considered. The main findings of the study are summarized below:

- Climatic fluctuations that occurred at the continental scale in South America during the 20th century modulated the hydrological dynamics of MPR, generating decadal wet/humid and dry scenarios. Commercial catches significantly increased during wet/humid periods when the frequency of duration of spring-summer floods was intensified.

- The composition of the commercial assemblage has undergone marked changes over time. Fish catches were positively related to interannual hydro-climatic variability, while the influence of anthropic variables related to fishing activity became significant in the last 2 decades of the 21st century due to changes in the fisheries production.

- Future hydro-climatic conditions predicted by available models (e.g., Camilloni et al., 2013; IPCC, 2014) do not favor commercial fisheries, since increasing extreme events and decreasing river discharge and connectivity are predicted, potentially reducing the reproductive success and catches of fish (particularly LM).

\section{ACKNOWLEDGMENTS}

This study was supported by the National Agency for Scientific and Technical Promotion of Argentina (Project PICT Nr 1855 2013-2015 and Project PIP 2014-2016 Nr 438). We are grateful to the Ministry of Production of Santa Fe which enabled our free access to relevant datasets (PPSF) of their files. We appreciate logistic support provided by the National Institute for Limnology of Argentina (INALI).

\section{DATA AVAILABILITY STATEMENT}

Databases are available from the National Institute of Limnology (INALI, CONICET-UNL). Requests can be done at secretaria@inali.unl. edu.ar, informing the reference of the work and the object of the request.

\section{ORCID}

Ana P. Rabuffetti (D) https://orcid.org/0000-0003-0106-0876

Elie Abrial (iD https://orcid.org/0000-0003-4563-5512

\section{REFERENCES}

Abrial, E., Espínola, L. A., Rabuffetti, A. P., Amsler, M. L., \& Wantzen, K. M. (2018). Interannual flow variability in a large subtropical-temperate floodplain: A challenge for fish reproduction. Canadian Journal of Fisheries and Aquatic Sciences, 76, 390-400. https://doi.org/10.1139/ cjfas-2017-0579

Agostinho, A. A., Pelicice, F. M., \& Gomes, L. C. (2008). Dams and the fish fauna of the neotropical region: Impacts and management related to diversity and fisheries. Brazilian Journal of Biology, 68, 1119-1132. https://doi.org/10.1590/S1519-69842008000500019

Antico, A., Schlotthauer, G., \& Torres, M. E. (2014). Analysis of hydroclimatic variability and trends using a novel empirical mode decomposition: Application to the Paraná River basin. Journal of Geophysical Research, 119(3), 1218-1233. https://doi.org/10.1002/ 2013JD020420

Arieira, J., Penha, J., Nunes da Cunha, C., \& Guimaraes Couto, E. (2012). Ontogenetic shifts in habitat-association of tree species in a neotropical wetland. Plant and Soil, 404, 219-236. https://doi.org/10.1007/ s11104-016-2844-y

Baigún, C. R. M., Minotti, P., \& Oldani, N. (2013). Assessment of sábalo (Prochilodus lineatus) fisheries in the lower Paraná River basin (Argentina) based on hydrological, biological, and fishery indicators. Neotropical Ichthyology, 11(1), 199-210. https://doi.org/10.1590/ S1679-62252013000100023

Baigún, C. R. M., Puig, A., Minotti, P. G., Kandus, P., Quintana, R., Vicari, R., ... Nestler, J. A. (2008). Resource use in the Parana River Delta (Argentina): Moving away from an ecohydrological approach? Ecohydrology and Hydrobiology, 5(2-4), 245-252.

Baldissera, R., Rodrigues, E. N. L., \& Hartz, S. M. (2012). Metacommunity composition of web-spiders in a fragmented Neotropical Forest: Relative importance of environmental and spatial effects. PLoS One, 7(10), e48099. https://doi.org/10.1371/journal.pone.0048099

Best, J. L. (2018). Anthropogenic stresses on the world's big rivers. Nature Geoscience, 12, 7-21. https://doi.org/10.1038/s41561-018-0262-x

Camilloni, I., Saurral, R. I., \& Montroull, N. B. (2013). Hydrological projections of fluvial floods in the Uruguay and Paraná basins under different climate change scenarios. International Journal of River Basin Management, 6, 389-399. https://doi.org/10.1080/15715124.2013.819006

Colautti, D., Domanico, A., \& Balboni, L. (2016). Proyecto de evaluación de los recursos ícticos del bajo Río Uruguay y el Río de la Plata interior. DPCMAGyP: CARU.

Del Barco, D. (2000). Informe sobre la Situación actual de la actividad pesquera en la provincia de Santa Fe. UNL, p. 13.

Escofier, B., \& Pagès, J. (1994). Multiple factor analysis (AFMULT package). Computational Statistics \& Data Analysis, 18, 121-140. https://doi.org/ 10.1016/0167-9473(94)90135-X

Espinach Ros, A., Dománico, A., Demonte, D., del Barco, D., Cordiviola, E., Campana, M., ... Mantinian, J. (2012). Evaluación del recurso sábalo (Prochilodus lineatus) en el río Paraná. In Período: 2008-2011, Argentina: Ministry of Agriculture, Livestock and Fisheries. Secretariat of Agriculture, Livestock and Fisheries. Undersecretariat of Fisheries and Aquaculture.

Espínola, L. A., Rabuffetti, A. P., Abrial, E., Amsler, M. L., Blettler, M. C. A., Paira, A. R., ... Santos, L. N. (2016). Response of fish assemblage structure to changing flood and flow pulses in a large subtropical river. Marine and Freshwater Research, 68(2), 319-330. https://doi.org/10. 1071/MF15141

Etchegoyen, M. A., Ronco, A. E., Almada, P., Abelando, M., \& Marino, D. J. (2017). Ocurrence and fate of pesticides in the argentine stretch of the Paraguay-Paraná basin. Environmental Monitoring and Assessment, 189(63), 1-12.

FAO. (2016). The state of world fisheries and aquaculture 2016. Contributing to food security and nutritional for all, Rome: Food and Agriculture Organization (FAO). pp. 200.

Barange, M., Bahri, T., Beveridge, M. C. M., Cochrane, K. L., FungeSmith, S., \& Poulain, F. (2018). Impacts of climate change on fisheries and aquaculture: synthesis of current knowledge, adaptation and mitigation options. FAO Fisheries and Aquaculture Technical Paper No. 627. Rome: FAO. pp. 628.

Fuentes, C. M., \& Quirós, R. (1988). Variación de la composición de la captura de peces en el río Paraná durante el período 1941-1984. INIDEP ISSN:0326-8659.78 
Górski, K., Buijse, A. D., Winter, H. V., De Leeuw, J. J., Compton, T. J., Vekhov, D. A., ... Nagelkerke, L. A. J. (2013). Geomorphology and flooding shape fish distribution in a large-scale temperate floodplain. River Research and Applications, 29, 1226-1236. https://doi.org/10. $1002 /$ rra. 2610

IPCC. (2014). Climate change 2014: Impacts, adaptation and vulnerability. Summary for policymakers. GT II. OMM, PNUMA.

Iwaszkiw, J. M., \& Lacoste, F. F. (2011). La pesca artesanal en la Cuenca del Plata y sus implicancias en la conservación de la biodiversidad. Revista del Museo Argentino de Ciencias Naturales, 13, 21-25.

Jackson, D. A (1993). Stopping rules in principal components analysis: a comparison of heuristical and statistical approaches. Ecology, 74, 2204-2214.

Junk, W. J., Bayley, P. B., \& Sparks, R. E. (1989). The flood pulse concept in river-floodplain systems. Canadian Journal of Fisheries and Aquatic Sciences, 106, 110-127.

King, A. J., Humphries, P., \& Lake, P. S. (2003). Fish recruitment on floodplains: The roles of patterns of flooding and life history characteristics. Canadian Journal of Fisheries and Aquatic Sciences, 60, 773-786.

Latrubesse, E. (2008). Patterns of an abranching channels: The ultimate end-member adjustment of mega-rivers. Geomorphology, 101, 130-145. https://doi.org/10.1016/j.geomorph.2008.05.035

McCasker, N., Humphries, P., Meredith, S., \& Klomp, N. (2014). Contrastng pattens of larval mortality in two sumpatric riverine fish species: A test of the critical period hypothesis. PLoS One, 9(10), e109317.

Oldani, N. O., Ecclesia, O., \& Baigún, C. R. M. (2013). Edad, crecimiento, mortalidad e incidencia de las variaciones del nivel hidrométrico del Río Paraná en la abundancia del surubí pintado (Pseudoplatystoma corruscans). Biologicals, 16, 25-38.

Oliveira, A. G., Baumgartner, M. T., Gomes, L. C., Días, R. M., \& Agostinho, A. A. (2018). Long-term effects of flow regulation by dams simplify fish functional diversity. Freshwater Biology, 63(3), 293-305. https://doi.org/10.1111/fwb.13064

Peres-Neto, P. R., Legendre, P., Dray, S., \& Borcard, D. (2006). Variation partitioning of species data matrices: Estimation and comparison of fractions. Ecology, 87, 2614-2625.

Prol, L. (2008). El sector pesquero en la provincia de Santa Fe: resultados preliminares de investigación. Posadas, Argentina: Universidad Nacional de Misiones.

Quirós, R. (1990). The Paraná River basin development and the changes in the lower basin fisheries. Interciencia, 15, 442-451.
R Development Core Team. (2014). R: A language and environment for statistical computing. Austria, Retrieved from: R Foundation for Statistical Computing. http://www.R-project.org

Rabuffetti, A.P. (2018). Influencia de la variabilidad climática sobre la composición de la comunidad íctica en el tramo medio del río Paraná. ( $\mathrm{PhD}$ Tesis). Universidad Nacional del Litoral.

Rabuffetti, A. P., Górski, K., Espínola, L. A., Abrial, E., Amsler, M. L., \& Paira, A. L. (2016). Long-term hydrologic variability in a large subtropical Floodplain River: Effects on commercial fisheries. River Research and Applications, 33, 353-363. https://doi.org/10.1002/rra.3100

Rossi, L., Cordiviola, E., \& Parma, M. J. (2007). Fishes. In M. H. Iriondo, J. C. Paggi, \& M. J. Parma (Eds.), The middle Paraná River. Limnology of a subtropical wetland. Germany: Springer-Verlag.

Scarabotti, P. A., Demonte, L. D., \& Pouilly, M. (2017). Climatic seasonality, hydrological variability, and geomorphology shape fish assemblage structure in a subtropical floodplain. Freshwater Science, 36, 653-668. https://doi.org/10.1086/693441

Schramm, H. L., Jr. (2017). The fishery resources of the Mississippi River: A model for conservation and management. Fisheries, 42, 574-585. https://doi.org/10.1080/03632415.2017.1377554

Sverlij, S., \& Espinach Ros, A. (1986). El dorado, Salminus maxillosus (Pisces, Characiformes) en el Río de la Plata y Río Uruguay inferior. Revista de Investigación y Desarrollo Pesquero, 6, 57-75.

Vargas, F. (2014). Informe final de Estadísticas Pesqueras del año 2013. Argentina: Departamento de Fauna y Pesca de la Dirección de Fauna y Áreas Naturales Protegidas. Ministerio de Producción de la Provincia del Chaco.

Winemiller, K. O. (2004). Floodplain river food webs: Generalizations and implications for fisheries management (Vol. 2). Bangkok: FAO.

Wong, M., Williams, E., Pittock, J., Ollier, U., \& Schelle, P. (2007). World's top 10 rivers at risk. Gland, Switzerland: WWF International.

How to cite this article: Rabuffetti AP, Espínola LA, Abrial E, Amsler ML, Eurich MF, Blettler MCM. The influence of hydroclimatic and anthropogenic effects on the long-term variation of commercial fisheries in a large floodplain river. River Res Applic. 2020;1-13. https://doi.org/10.1002/rra.3741 